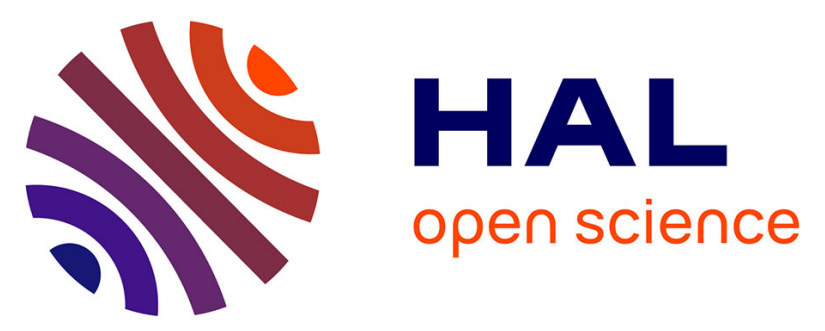

\title{
Cardiac rehabilitation in chronic heart failure: effect of an 8-week, high-intensity interval training versus continuous training
}

Céline Freyssin, Fabrice Prieur, Chantal Verkindt, Philippe Benaich, Sébastien Maunier, Philippe Blanc

\section{To cite this version:}

Céline Freyssin, Fabrice Prieur, Chantal Verkindt, Philippe Benaich, Sébastien Maunier, et al.. Cardiac rehabilitation in chronic heart failure: effect of an 8-week, high-intensity interval training versus continuous training. Archives of Physical Medicine and Rehabilitation, 2012, 93 (8), pp.1359-1364. 10.1016/j.apmr.2012.03.007 . hal-01232322

\section{HAL Id: hal-01232322 \\ https://hal.univ-reunion.fr/hal-01232322}

Submitted on 28 Oct 2016

HAL is a multi-disciplinary open access archive for the deposit and dissemination of scientific research documents, whether they are published or not. The documents may come from teaching and research institutions in France or abroad, or from public or private research centers.
L'archive ouverte pluridisciplinaire HAL, est destinée au dépôt et à la diffusion de documents scientifiques de niveau recherche, publiés ou non, émanant des établissements d'enseignement et de recherche français ou étrangers, des laboratoires publics ou privés. 


\title{
Cardiac rehabilitation in chronic heart failure: effect of a 8-week high- intensity interval training vs continuous training with regard to variables commonly used in clinical practice
}

\author{
Céline Freyssin (1), Fabrice Prieur (2), Chantal Verkindt (3), Philippe \\ Benaich (1), Sébastien Maunier (1), Philippe Blanc [Orateur] (1) \\ (1) Centre de Rééducation Cardiaque Sainte Clotilde, Sainte Clotilde Cedex, \\ France - (2) Laboratoire AMAPP, EA 4248, Université d'Orléans, France, \\ Orléans, France - (3) Laboratoire DIMPS, EA4075, Université Réunion, \\ France, Le Tampon, France
}

Purpose: It has been demonstrated that aerobic interval training is feasible for the treatment of heart failure. It can be superior to continuous training for patients with post infarction heart failure.

The objective of this study was to compare the effects of a short innovative high-intensity interval training protocol versus continuous retraining on aer-obic capacity and functional capacity in patients with chronic heart failure (CHF).

Methods: 26 patients with CHF were enrolled in a 8-week cardiac rehabil-itation program. Patients were divided into two groups: one group performed rehabilitation with interval training exercises (IT) and the other group per-formed rehabilitation with continuous training exercises (CT). IT consisted in 3 series of 12 repetitions of $30 \mathrm{sec}$ of exercise, followed by $60 \mathrm{sec}$ of rest. The exercise intensity was 50 and $80 \%$ of the maximal power reached during a steep ramp test during the first 4 weeks and the last 4 weeks, respectively. CT consisted in 45 minutes of aerobic exercise corresponding to the heart rate at the first ventilatory threshold. Parameters of the physical capacity were assessed using a treadmill ramp test with gas exchange measurements and using a 6 minute walk test (6MWT).

Results: The IT group increased their peak $\mathrm{VO}_{2}(\mathrm{p}<0.001)$, the duration of the exercise test $(\mathrm{p}<0.001)$, the oxygen pulse $(\mathrm{p}=0.029) \mathrm{VO}_{2}$ and the time at the second ventilatory threshold $(\mathrm{p}=0.006$ and $\mathrm{p}<0.001)$, and the distance performed at the 6MWT $(\mathrm{p}<0.001)$. The CT group increased only the time at the second ventilatory threshold $(\mathrm{p}=0.004)$ and the distance performed at the $6 \mathrm{MWT}(\mathrm{p}=0.050)$ and these improvements were significantly higher for the IT group than for the CT group ( $\mathrm{p}=0.047)$.

Conclusion: This study shows that, in patients with CHF, 8 weeks of high intensity interval training included in a rehabilitation program appears to be more effective than continuous training to improve some parameters of phys-ical capacity. 